\title{
A Review of Climate Change and its Effects in the Western Mountainous Water Basin of Nepal
}

\author{
Dr. Raghu Bir Bista, Dr. Khet Raj Dahal and Dr. Ram Prasad \\ Gyawali
}

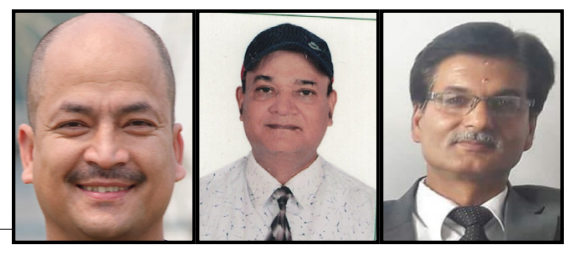

Dr. Raghu Bir Bista Dr. Khet Raj Dahal Ram Prasad Gyawali

\begin{abstract}
This study was conducted in the period of January 2014 to December 2015. The main objective of the study was to investigate the impact of climate change in the water basin and its catchment areas. The method was a survey of relevant literatures. Climate change is a big issue not only in developed countries but also in developing countries. The study found that the temperature is rising with $2.0^{\circ} \mathrm{C}$ on average per annum in western Nepal. This is relatively 3 times higher than lower temperature increase within the country and significantly higher in comparison to global trend of temperature variation. Over the last 36 years (1975-2010) in western Nepal, temperature is rising on an average of $1.2^{\circ} \mathrm{C}$ per annum. This is twice as compared to the global increment. This indicates more vulnerability of climate change in hills and high hills of Nepal. The average rise of temperature in Nepal is $0.06^{\circ} \mathrm{C}$ per year. The climate-induced disasters are; drought, severe floods, landslide, etc. They also have negative effects in agriculture in the hills and high hills of Nepal.
\end{abstract}

Keywords: Climate change, vulnerability, disaster, river basin, environmental deterioration, Nepal

\section{Introduction}

Climate change is an emerging issue across the world. Despite being a trans-boundary/global issue, it could not receive any attention until the book, The Limits to Growth was published in 1972. Interestingly and surprisingly, the book had raised a query about the sustainability of the Earth by analyzing twelve growth scenarios of global development over 200 years from 1900 to 2100 , through the first use of world prediction model. Its key finding was the increasing natural depletion induced climate change. This would be the 'limits to growth'. Therefore, there was a strong warning that humankind will reach its limits of growth within 100 years if the world population and industrial development continue to increase, exacerbating resource depletion and the environmental deterioration (Behrens, Randers, Meadows and Meadow, 1972). It was a great research on resource depletion, environmental deterioration and climate change and its relationship with the population and industrial growth. Further, over population and industrial growth were argued as key drivers of climate change. After that, climate change emerged as a concerning issue at that time.

After 15 years later in 1987, the Montreal Protocol captured this issue related to ozone layer depletion through the limitation of use of halogenated hydrocarbons. Furthermore, the United Nations through the Brundtland Commission (the World Commission on Environment and Development) followed this issue in 1987. The commission endorsed the concept of sustainable development for first time in the book, Our Common Future.

Gradually, the research successfully opened the eyes of the government. Thereafter, it received serious attention of the governments of the different countries.
Then, they requested United Nations to establish scientific intergovernmental body for further concerns. UN, UNEP and the World Meteorological Organization (WMO) in the framework of UNFCCC (United Nations Framework Convention on Climate Change) established the Intergovernmental Panel on Climate Change (IPCC) in 1988. Thus, this trans boundary issue was in the international treaty as UNFCCC had the objective of stabilization of greenhouse gases (GHG) in the atmosphere. It was the beginning of international response in terms of institutional development and framework and research activity on climate change. IPCC as UN's inter-government institution was a big achievement for climate change research.

There are two blocks of research available on climate change: institutional and individual research. IPCC has led to institutional research as follows:

In 1990, IPCC published the first assessment report on climate change and thematic issues after a comprehensive evaluation. The assessment report mentioned human induced emissions as drivers of substantial GHG concentration in the atmosphere and found further global mean temperature growth of $0.3^{\circ} \mathrm{C}$ per decade of business as usual (BAU). Over the last 100 years, the growth of global mean surface air temperatures was found to be in the range of $0.3^{\circ} \mathrm{C}$ to $0.6^{\circ} \mathrm{C}$. This indicates climate change in the world (IPCC, 1990).

In 1992, IPCC conducted further studies on climate change and produced a supplement report in which IPCC concluded no augmentation on our fundamental understanding of the science of the GHGs (IPCC, 1992). In 1995, the IPCC explained the growth of GHGs concentration in the atmosphere due to human made and natural activities as drivers of temperature rise 
between $0.3^{\circ} \mathrm{C}$ and $0.6^{\circ} \mathrm{C}$, since 19 th century. The second assessment report expected the further temperature rises in future, despite the occurrence of uncertainties (IPCC, 1995).

The third assessment report (TAR) published in 2001 noted that the projected climate change would have negative impacts on both environmental and socioeconomic systems with the larger changes in climate. Further, the report identified vulnerable ecosystems and species. Mitigation and adaptation could lessen GHG pressure and the effects of climate change (IPCC, 2001a).

Similarly, IPCC published a fourth assessment report (AR4) in 2007. IPCC (2007) explained increasing climate change impacts as growing frequencies and concentration of some extreme weather events, experience in rising warming and sea level, despite business as action including available of mitigation and adaptation activity.

Lastly, a fifth assessment report (AR5) in 2014 had argued human influence on the climate system between 1951-2010 and increasing likelihood of severe, pervasive and irreversible impacts due to the increasing magnitude of global warming. IPCC (2014) explained that adaptation to future climate change leads to reduce vulnerability and exposure to present climate variability and the overall risks of climate change impacts decreases while in the limit of the rate and magnitude of climate change.

In addition, the United Nations Conference on Environment and Development held in Rio de Janeiro in 1992 and the World Summit on Sustainable Development held in Johannesburg in 2002 have expanded the concept of sustainable development all over the world. UNEP released the Global Glacier Changes: Facts and Figures in 2008 focusing on the fluctuations of glaciers and ice caps. The report confirms double average annual melting rate of glaciers since the turn of millennium. Further, UNEP Year Book 2009 had followed again ice loss from ice sheets and glaciers.

At individual level, scientists have attempted their research on climate change as supplementary and complementary to IPCC's initiation on climate change. Stern's Review (2006) and Elisch Review (2008) are significant research contribution in many literatures.

\section{Climate Change at Global Level}

Climate change refers to climate variability. Human society had not noticed this natural phenomenon until 1972. It happened in 1900 and before 1900 (Behrens, Randers, Meadows and Meadow, 1972). Thus, the book, The Limits to Growth conceptualized natural resource depletion, environmental deterioration induced climate change. Large number of literatures (IPCC, 1990; IPCC, 1992; IPCC, 1995; IPCC, 2001; Ramos-Martin, 2001a;
UNFCCC, 2002a; Rabindranath and Sathaye,2003; Owen and Hanley, 2004; Watkiss et al., 2005; Stern, 2006; IPCC, 2007; UNFCC, 2007; Elisch, 2008; and IPCC, 2014) refer climate variability to climate change.

Climate change is the variability of heterogeneous climatic variables such as temperature, sea level, raining etc. Over 200 years from 1900 to 2100 , there was resource depletion and environmental deterioration (Behrens, Randers, Meadows and Meadow, 1972). Ozone layer depletion is another aspect of climatic change (WECD, 1987). Most of the warming ( $0.1^{\circ} \mathrm{C}$ per decade) observed over the last 50 years is attributable to human activity (IPCC, 2001). Furthermore, increase in global average air and ocean temperatures, widespread melting of snow and ice, and rising global mean sea level are evident (IPCC, 2007). Salinger (2005) added the trends of climate variability in the twenty first century as follows: a) the regular rapid temperature increases in high latitudes of Northern Hemisphere, b) drying in Mediterranean areas, and c) increasing climate variability especially in sub-tropical and tropical latitudes. Hansen and Ruedy (2011) found that average annual temperature was higher in the winter than in the summer and higher over land than over the ocean. Its reason was the huge difference in temperature between low latitude and high latitudes in winter. Thus, climate change is aggregate change in climatic variables over long time.

Climate change in the world is global climate change (IPCC, 2001; Ramos-Martin, 2001a; UNFCCC, 2002a; Ravindranath and Sathaye, 2003; Owen and Hanley, 2004; Watkiss et al., 2005). It is a global 'public bad', in which both physical and economic actions and their feedback determines potential risks to human and the environment. It is the classic example of a global stock externality - the flow of GHG emissions accumulates into a global carbon stock that poses risks to humanity around the globe (Owen and Hanley, 2004). The growth of GHG concentration in the atmosphere is due to two drivers: human induced economic activities and natural activities (IPCC, 1995). Human induced economic activities include construction, buildings, road development, agricultural, industrial and service activities for generating employment opportunities, welfare and higher economic growth rates. Its rate has been increasing with respect to the growth of population (Sterns, 2006). Similarly, in natural activities, there is fire led deforestation. Thus, the growth of GHG concentration and climate change as global 'public bad' has positive correlation with over population/ anthropogenic activities and development.

The growth of global public bad is a threat, challenging humanity with negative implications on food production, natural ecosystems, fresh water supply, health, etc. Ravindranath and Sathaye (2003). UNFCC (2007) established the adverse relationship between climate change and human activities by stating that 
climate change refers a change of climate affecting directly or indirectly to the human activities that change the composition of the global atmosphere, and then the natural climate variability observed over comparable time period. USGS (2007) has pointed out similar data but has specifically noted that climate affects every dimension of life on earth including human health and well-being, and agriculture, water and energy resources.

The distribution of climate change across the world is uneven. It distributes vertically and horizontally all over the world (Sterns, 2006). Its impact depends on the variation on adaptation capacity and behavior as well as mitigation activities among countries (IPCC, 2001 and Sterns, 2006). Horizontally, its impact distribution is across the world but vertically, its socio-economic impact is less in developed countries than developing countries. In other words, the developing countries are socioeconomically more vulnerable than developed countries based on adaptive capacity and behavior (Sterns, 2006 and IPCC, 2001a). Adaptive capacity and behavior are determining variables in the distribution of its intensity, despite its horizontal distribution. Its higher adversities are further in human activities, particularly production, consumption and development activities. Measuring such adversities in different sectors has been studied by Hassan (2008), Hanif, Syed, Ahmad and Malik (2010), Joshi and Thapa (2010), Kurukulasuriya and Ajwad (2004), Mendelsohn, Nordhaus and Shaw (1994), Mirza and Schmitz (2011), Seo Mendelsohn, Dinar, Hassan and Kurukulasuriya (2009), Seo and Mendelsohn (2008), Shrestha, and Maharjan and Joshi (2012). Its impact on agriculture is serious (Kurukulasuriya and Ajwad, 2004, K.C., 2013, and Seo and Mendelsohn, 2008). These literatures have measured the impact of climate change empirically estimated by three popular approaches: a) Agricultural processing approach, b) Ricardian approaches and c) Profit functional approach. Thus, the higher intensity of climate change has adverse effects across the world and is a big threat to humans and nature.

\section{Climate Change at National Level}

Nepal is one of the least developing nations struggling to become a developing nation. It is not free from the issue of climate change. On this issue, there are numerous studies at institutional as well as at individual level on this issue. In addition, some empirical literatures on climate change and its impacts are reviewed.

In Nepal, there is average rise of temperature by $0.06^{\circ} \mathrm{C}$ per year. The rise from 1975 to 2006 is nearly at $1.8^{\circ} \mathrm{C}$ (Malla, 2008). In addition to that, there are problems of frequent drought, severe floods, and landslides (Malla, 2008). These findings of the study by Malla (2008) on the concept of climate change and its impacts on agriculture are based on secondary information.
Climate change has mixed effects on agricultural crops in Nepal. $\mathrm{CO} 2$ enrichment technology in rice and wheat at Khumaltar results the yield of rice and wheat increased by $26.6 \%$ and $18.4 \%$ due to double $\mathrm{CO}_{2}$, but the increase of temperature results the yield of rice and wheat by $17.1 \%$ and $8.6 \%$ respectively (Malla, 2008). A crop simulation model (CSM) to study the effects of $\mathrm{CO} 2$, temperature and rain on rice and wheat in Nepal Agricultural Research Council (NARC) indicated the positive effect in yield of rice and wheat in all regions, but negative effect in maize especially in Terai. Further, it indicates the need of adaptive measures in Nepalese agriculture to mitigate the effects of climate change, to reduce the unpredicted natural disaster and distresses due to recent irregular weather pattern (Malla, 2008).

Contrarily, there was negative effect of climate change on rice production and productivity, when there were variance impacts on the growth level of rice and its yield in the condition of raising a $1^{\circ} \mathrm{C}$ daytime maximum temperature and rising rice production by $27 \mathrm{~kg} / \mathrm{ha}$. When daytime maximum temperature increased to $29.9^{\circ} \mathrm{C}$, the productivity declined. In higher average temperatures than this threshold, rice yields would probably lessen with any increment in maximum temperature. In the nursery stage of rice, rainfall had a strong negative effect on yield. Rice yield dropped in Nepal by about 5.2 percent relative to current production levels (Karn, 2014). This result was of the study of Karn (2014) on the sensitivity of rice yields to changes in climate variables and the magnitude of potential impacts on rice productivity in the future. The study covered 20 districts of Nepal out of 75 districts, in Terai region by employing the panel data sets of a 25-year period (19842008) of annual rice yields and daily observations on weather variables. The study used multiple regression method based on Ricardian method.

Joshi and Thapa (2010) assessed the impact of climate change on Nepalese agriculture by using crosssection data of 656 farm household across 14 districts covering all climatic zones of Nepal, by employing Ricardian approach, in which net farm income was regressed only with climate variables in Model I and then with both climate and socio-economic variables. The explanatory variables included the linear and quadratic terms of precipitation and temperature for the four seasons (winter, spring, summer and the fall), household variables, land and ratio of irrigated land. The study also calculated marginal impacts of climate change on agriculture, both based on season and climatic zone, in order to explore the variation of effects on different seasons and climatic zones. The study found a significant impact of climate variables on net farms income per hectare across Nepalese farm household, indicating both positive and negative impact of precipitation and temperature. Net revenue of the farm is likely to be enlarged with low precipitation and high temperature 
during the fall and spring seasons, which are the major harvesting seasons of Nepal. Farmers were likely to increase their revenue with relatively low temperature and enough precipitation during the summer period. The socio-economic variables also have impact on net farm income. For instance, net farm income was likely to be high on irrigated farmland combined with obtaining farm credit. But small farms managed better and obtained higher net income per hectare than large farms. The marginal impacts of climate change on agriculture were found to be in line with the second model. However, there were few variations in the marginal impacts. For example, winter precipitation had positive impact on farm value in Model 1, but not significant on Model 2, while winter temperature had negative impact on farm value. The quadratic terms of spring and fall precipitations had positive impact on net farm income per hectare, but not in summer and winter precipitations. Likewise, fall temperature was likely to increase net farm income.

The marginal impacts based on the climate are found few significant variables. Annual precipitation was likely to increase crop output in hills but reduced in Terai. Finally, the study found some interesting results to understand the impact of climate change on Nepalese agriculture. As there was a variation in the impact of the climate change (i.e., change on precipitation and temperature) on agriculture in different seasons and climatic zones, policies are needed to address these negative impacts of climate change in the country. The study indicated the need of further study to measure the impact of climate change on agriculture by using more advance models such as agronomic-economic and Computational General Equilibrium (CGE) models.

Acharya and Bhatta (2013) aimed to explore the time trend of agriculture gross domestic product (AGDP), use of agriculture inputs (chemical fertilizer, improved seeds etc.), precipitation, and temperature and their role in agricultural production of Nepal. The study used data sets of AGDP, agricultural inputs and climatic variables collected from 15 districts out of 75 districts for the period of 36 years (from 1975 to 2010) by using quantitative modeling.

The study found the statistical result of a significant positive relationship of rainfall to the AGDP in Nepal, where more rainfall means higher rate of AGDP growth and then higher rate of GDP growth due to the dominant contribution of AGDP in GDP. Furthermore, the rise in temperature might largely affect the AGDP. Their relationship was statistically insignificant. Similarly, seeds and chemical fertilizer inputs had no effect on AGDP. Their statistical relation was insignificant. The study observed that agricultural growth largely depended upon rainfall in developing countries like Nepal due to the lack of sufficient and reliable irrigation facilities. In case of rainfall, it was affected by temperature variation.
The study concluded occurrence of direct and indirect impact of climate change on the gross domestic product (GDP).

The study raised question on the stability of economic growth of Nepal due to the fluctuated monsoon-based growth. In drought, the study found negative impact on AGDP, energy output of the run-of-river hydropower and economic growth. Therefore, the study emphasized on the development of the irrigation systems, rather than the betterment of seeds and supply of funded biochemical manures. The spatial information should be used to bring forward the adaptive policies on the required areas within the nation to mitigate the consequences.

Pant (2012) examined the impacts of climate change on food security in the country in the context of policies on commercialization of farm production in his paper on 'Climate change and Food Security in Nepal' based on literature review and analysis of secondary data. Time series of secondary data on agriculture, rainfall and temperature were collected from publications of the Ministry of Agriculture and Cooperatives (MoAC) and Department of Hydrology and Meteorology (DHM) and analyzed. Similarly, food production data was collected from MoAC. In the method of analysis, statistical and econometric techniques were applied.

Bartlett, Bharati, Pant, Hosterman and McCornick (2010) examined how the impacts of climate change at different scales in Nepal (from household livelihoods to national food security) and how many institutions are employing adaptation. This study used theoretical literature review based on the secondary information and published materials.

This study found the negative impact of climate change (CC) on water resources and then further on agricultural systems and food security. Such impacts are more critical to a least developed country (LDC) like Nepal. Therefore, it was relevant to draft and begin implementing national adaptation plans. Further, the study focused on effective adaptation in the integrated national planning across all sectors and new infrastructure development (e.g., irrigation, hydropower etc.) for longer term. For autonomous adaptation, the study focused more on building and expanding basic infrastructure at the local level, providing greater income diversification and access to markets. Such infrastructure would improve inter-connectivity between isolated communities, national government institutions and nongovernmental organizations (NGOs).

The study found that overcoming fundamental failures of governance and institutional effectiveness is possible through basic development and effective strategic adaptation planning and implementation. Therefore, the study indicated the need of capacity building on 
CC impacts in various government departments and ministries. Furthermore, developing water management strategies as well as agricultural diversification plans should be emphasized.

\section{Climate Change at Local Level}

Western Nepal is not free from climate change either. There are handful empirical studies on this part of Nepal, out of which most relevant studies are reviewed.

In western Nepal, temperature rise has been $2.0^{\circ} \mathrm{C}$ average per annum. It is relatively 3 times higher than the lower temperature of the country and significantly higher in the comparison to global trend of temperature variation. Over the last 36 years $(1975-2010)$ in western Nepal, average temperature rise is $1.2^{\circ} \mathrm{C}$; that is twice more of the global average. It indicates higher vulnerability to climate change in hills and high hills (Acharya, 2012). This is the result of Acharya's (2012) study on the impact of climate change on agriculture in Nepal using time series data via econometric model. Thus, climate change occurs in western Nepal.

Bhandari (2013) examined the effect of precipitation and temperature variation on the yield of two major cereals (rice and maize) in Dadeldhura District of Far Western Development Region, Nepal by using rice and maize and two climate variables (temperature and rainfall). Data sets of these variables were collected from secondary sources of Dadeldhura District of Far Western Development Region using quantitative method.

He found that high temperature and low rainfall unpleasantly affected the rice and maize yield. There were some exceptional variety of wheat, millet and barley having tolerance in such climatic variations. They gave substantial yield. In recent days, climate change has severe consequences of agricultural productivity and production, specifically in developing countries like Nepal. Such consequences were heterogeneous with respect to a change in the level of temperature and rainfall. Sometimes it would be beneficial, while sometimes it would be harmful because of the changing season, altitude and type of crop. In this severe sensitivity, cereal varieties that are specifically adapted should be planted to mute the adverse effects of climate change. The government of Nepal should response urgently on two key options: the supply of timely climate information and the development of climate-resilience (temperaturetolerance). Therefore, future studies should analyze data in regional level to capture regional variations in yield with some other variables including rainfall and temperature to obtain a more comprehensive image on the yield of major cereals in Nepal.

Pant (2011) discussed the potential economic impacts of the climate change on small holder farming communities in Nepal by using theoretical and empirical papers published in different journals. It was based on secondary information covering climate change, small holder farming and communities. It used literature review and deductive logic method.

He found direct and indirect costs of climate change and costs of adaptation to the farmers. In direct cost, there were cost of decreasing crops and livestock and increasing cost of production, along with cost from the increased risks of natural hazard. In indirect cost, there were costs of change in socio-economic conditions, lost opportunities for the improvement in living conditions, and adaptation costs. He indicated heavy costs of climate change, higher than the benefits of the farmers. In the benefit, there were shortening crop life cycle, increasing to growing seasonal time and carbon fertilization increasing the crop production.

The study focused on policy measures for reducing the costs of the climate change the farmers bear. The study argued the importance of interventions such as variety, drought tolerant livestock, irrigation infrastructure and suitable farming technology for the farmers. In addition, it emphasized on the creation of off-farm employment opportunities and found them less affected by climate change than the agricultural sources of income. It mentioned the need of farming system researches for identification of location, and endowment specific management tradeoff suitable for the poor farmers. It gave the importance of national and international policy measures for the compensating the farmers for the costs due to climate change, the need of public sector investment in agricultural production to safeguards the farmers from the vagaries of climate change, and the need of agricultural research program to develop technologies necessary for climate change adaptation. At the end, the study opened up new research areas of quantification of the costs and benefits of the climate change in relation to the farmers and also to the food security of the nation.

\section{Conclusions}

Climate change is an emerging threat in the developing world. The literatures indicate climate change in Nepal with $0.06^{\circ} \mathrm{C}$ average per year temperature rise. In western $\mathrm{Nepal}$, the temperature rise is $2.0^{\circ} \mathrm{C}$ on average. It is relatively 3 times higher than lower temperature within the country and significantly higher in the comparison of global trend of temperature variation. The climate change-induced disasters which are drought, severe floods, landslide, etc have negative impacts on agricultural farms, particularly rice and maize, and food security in the hills and high hills of Nepal.

\section{Acknowledgements}

We would like to acknowledge to University Grant Commission (UGC), Sanothimi, Dean Office, Faculty 
of Social Science and Humanities, Central Department of Economics, Patan Multiple Campus Tribhuvan University for their valuable support. In addition, we would like to acknowledge to Associate Professor Dr. Ranjan Kumar Dahal, Dr. Manita Timilsina, Dr. Ganga Lal Tuladhar, Deepak K.C., UNDP, Dr. Shreedhar Thapa, Associate Professor Tara Bhusal, and Assistant Dean Dr. Rajkumar Pokharel, Mr. Keshab Poudel, Mr. Budhi Prasad, Sundar Nepal and Prof. Joyshree Roy for their contribution during the preparation of this paper.

Raghu Bir Bista, PhD, is Assistant Professor of Economics, Tribhuvan University. He received his $\mathrm{PhD}$ on Climate Change Vulnerability and Household Adaptation in Nepal in economics from Tribhuvan University, Nepal in 2017. He completed his Master of Philosophy from Jadavpur University, Calcutta, India. E-mail: bistanepal@gmail.com

Khet Raj Dahal, PhD, is the campus chief of Lumbini International Academy of Science and Technology (LIAST), Lalitpur, Nepal. He completed his Ph.D. from Kathmandu University in 2014 in the department of Environmental Science and Engineering, M. Sc in Engineering from St. Petersburg University of Architecture and Civil Engineering in 1993, M. A. in Sociology in 1999 from Tribhuvan University and M.Sc. in Ecology and Environment in 2004, Institute of Ecology and Environment, New Delhi. He is the winner of the best writer in environment in 2005 in Lumbini Zone, Nepal.

Corresponding E-mail: dahal.khetraj@gmail.com

Ram Prasad Gyawali, PhD, is a Professor of Economics, Tribhuvan University. He received his $P h D$ in Economics from Banaras Hindu University, Varanasi, India in 2007. His area of specialization is macroeconomics, monetary economics and econometrics. He was a member of Revenue Advisory Board, the Ministry of Finance, Government of Nepal. E-mail:ramgyanwaly@gmail.com

\section{References}

Acharya, S. P. (2012). Is climate change engulfing Nepal faster? Mirmire (English Edition). 40 (312), 5.

Acharya, S. P. and Bhatta, G.R. (2013). The impact of climate change on agricultural growth in Nepal. Working paper series, 15(201).

Bartlett, B., Bharati, L., Pant, D., Hosterman, H., and McCornick, P. (2010). Climate change impacts and adaptation in Nepal. IWMI Working Paper, 139.

Bhandari, G. (2013). Effect of precipitation and temperature variation on the yield of major cereals in Dedeldhura Districts of Far Western Development Region, Nepal. International Journal of Plant, Animal and Environmental Sciences, 3(1), Jan- Mar.

Elisch, J. (2008). Climate change: Financing global forests. London: The Stationary Office Limited.

HanifUzma, Syed, S.H., Ahmad, R., and Malik, K.A.
(2010). Economic impact of climate change on agricultural sector of Punjab, publication in 2009retrieved from http://www.pide.org.pk/ psde/25/pdf/agm26/day3/Uzma\%2oHanif.pdf.

Hansen, J., Sato, M. and Ruedy, R. (2011). Climate variability and climate change: The New climate dice. New: The Goddard Institute for Space Studies (GISS).

Hassan, R. (2008). Implications of climate change for agricultural sector performance in Africa: Policy challenges and research agenda. Journal of African Economics 19(2): 77-105.

IPCC (1990). First Assessment Report of Climate Change. Cambridge: Cambridge University Press.

IPCC (1992) Supplementary Report of Climate Change. Cambridge: Cambridge University Press.

IPCC (1995) Second Assessment Report of the IPCC. Cambridge: Cambridge University Press.

IPCC (2001a). Climate change 2001: Impacts, adaptation and vulnerability. Summary for policymakers, Cambridge: Cambridge University Press.

IPCC (2001b). Third Assessment Report of the IPCC. Cambridge: Cambridge University Press.

IPCC (2007). Working Group II Summary for Policy Makers. Cambridge: Cambridge University Press.

IPCC (2014) Fifth Assessment Report of Climate Change. Cambridge: Cambridge University Press.

Joshi, G.R. and Thapa, S. (2010). A Ricardian analysis of the climate change impact on Nepalese agriculture. Paper submitted to International Conference of Biodiversity, Livelihood and Climate Change in the Himalayas12-14 December 2010, Kathmandu, Nepal

K.C., S. (2013). Community vulnerability to floods and landslides in Nepal. Ecology and Society 18(1), 8, Published in 2012 retrieved from http://dx.doi. org/10.5751/ES-05095-180108.

Karn, P. K. (2014). The impact of climate change on rice production in Nepal. SANDEE Working Paper No. 85-14. Kathmandu: SANDEE

Kurukulasuriya, P. and Ajwad, M.(2004). Estimating the impact of climate change on smallholders: A case study on the agricultural sector in Sri Lanka. In Mendelsohn R et al. (eds), Cross-Sectional Analyses of Climate Change Impacts. World Bank Policy Research Working Paper No. 3350.

Malla, G. (2008). Climate change and impact on Nepalese agriculture. Journal of Agriculture and Environment, 9(5).

Meadows, Donella H; Meadows, Dennis L; Randers, Jørgen; Behrens III, William W (1972). The Limits to Growth; A Report for the Club of Rome's Project on the Predicament of Mankind (PDF). New York: Universe Books. ISBN 0876631650. Retrieved 26 November 2017.

Mendelsohn, R., Nordhaus, W.D. and Shaw, D. (1994). The impact of global warming on agriculture: A Ricardian analysis. The American Economic Review, 753-771.

Mirza Nomman, A and Schmitz, P.M. (2011). Using the Ricardian Technique to estimate the impact of Climate change on crop farming in Pakistan 
paper prepared for presentation at the EAAE 2011 Congress, Switzerland.

Owen, A and Hanley, N (eds) (2004) The economics of climate change. London: Taylor and Francis Group.

Pant, K.P. (2011). Economics of climate change for smallholder farmers in Nepal: A Review paper, The Journal of Agricultural and Environment, 12(5).

Pant, K.P. (2012). Climate change and food security in Nepal. The Journal of Agricultural and Environment, 13(5).

Ramos-Martin, J(2001a). Historical analysis of energy intensity of Spain: From a conventional view to an integrated assessment. Population and Environment, 22(3):281-313.

Ravindranath, N. and Sathaye, J (2003). Climate change and Developing countries. New York: Kluwer Academic Publishers

Salinger, M. J. (2005). Climate variability and change: Past, present and future - An overview. Hamilton: National Institute of Water and Atmospheric Research.

Seo, N. and R. Mendelsohn. (2008). A Ricardian analysis of the Impact of climate change on South American farms. Chilean Journal of Agricultural Research, 68(1), 69-79.

Seo, N.S., R. Mendelsohn, A. Dinar, R. Hassan, and P. Kurukulasuriya (2009). A Ricardian analysis of the distribution of climate change impacts on agriculture across agro-ecological zones in Africa. Environmental Resource Economics, 43, 313-332.
Shrestha, S.L., Maharjan, K.L., and Joshi, N.P. (2012). Relationship between Climate Variables and Yields of Food crops in Nepal: Cases of Makwanpur and Ilam Districts. Journal of International Development and Cooperation, 18(4), 37- 54.

Sterns, N. (2006). The Economics of Climate Change. London: H.M Treasury.

United Nations Framework Conventions on Climate Change (UNFCCC). (2002a). Climate change: Impacts, vulnerabilities and adaptation in Developing countries. Bonn: UNFCCC Secretariat.

United Nations Framework Conventions on Climate Change (UNFCCC). (2007). Climate change: Impacts, vulnerabilities and adaptation in Developing countries. Bonn: UNFCCC Secretariat.

United States Geological Survey (USGS) (2007). Climate variability and change: Facing tomorrow's challenges-USGS Science in the Decade 2007-2017, Publication in 2006 retrieved from http://pubs. er.usgs.gov/usgspubs/cir/cir1309

Watkiss, P., D. Anthoff, T. Downing, C. Hepburn, C. Hope, A. Hunt and R. Tol, (2005). The social costs of carbon (SCC) review: Methodological approaches for using SCC estimates in policy assessment, Final Report. London: Department for Environment, Food and Rural Affairs (Defra) retrieved from http:// www.defra.gov.uk/environment/climatechange / research/carboncost/pdf/ aeat-scc-report.pdf 